\title{
$R$ \& D indicators and mapping of solar energy research output in India
}

\author{
Malti Goel*, Vandana Maurya, Pranav N. Desai \\ Center for Studies in Science Policy, School of Social Sciences, Jawaharlal Nehru University, New Delhi, India
}

\begin{abstract}
Solar electricity is a clean energy solution for Sustainable Energy. Solar photovoltaic program in India began in early 1980 s. India announced the Jawaharlal Nehru National Solar Mission for accelerating solar electricity growth in 2010. A target of achieving 20,000 MW of solar electricity by 2022 has been set. This paper presents current solar energy scene in India, carries out a study of R\&D indicators, and makes an assessment of research output. 'Web of Science' R\&D publications from 2000-2009 in India vs. world have been analyzed. India is among the five leading countries in research publications, but in the overall analysis, India is lagging behind. The study provides a baseline in research output just before the start of the national solar mission and establishes the need for increasing R\&D investment many folds for meeting the set targets.
\end{abstract}

Key words: Bibliographic analyses, R\&D indicators, solar energy research, National solar mission

\section{INTRODUCTION}

India's progressively increasing economic growth, with increasing population and its ever increasing energy demand, has led to harness electricity from the renewable sources of energy to most of its capacity. As per the energy technology perspectives baseline scenario 2010 of International Energy Agency, ${ }^{[1]}$ India's primary energy use is expected to quadruple during 2007-2050. Gross domestic product is expected to increase eightfold, and $\mathrm{CO}_{2}$ emissions would increase by almost 5 times. India's share in total global $\mathrm{CO}_{2}$ emissions is projected to double from current 5 per cent to about 11 per cent.

Solar Photovoltaic (SPV) Program of India was conceived in late 1970s in response to the world oil crisis, as one of

*Address for correspondence:

E-mail: maltigoel2008@gmail.com

\begin{tabular}{|l|l|}
\hline \multicolumn{2}{|c|}{ Access this article online } \\
\hline Quick Response Code: & \\
\hline & Website: \\
\hline & www.jscires.org \\
\cline { 2 - 3 } & DOI: \\
\hline
\end{tabular}

the largest national programs in the world. The SPV energy development in the country begun in early 1980s with three main objectives; (1) Research on solar cell materials, (2) Development of production and manufacturing capabilities of SPV module, and (3) Promotional measures and incentives for installation of SPV electricity in strategic application areas and in remote inaccessible areas. ${ }^{[2]}$ There have been several new initiatives and new incentives subsequently. The thrust was given to decentralized rural applications for agricultural water pumping, lighting as well as low temperature applications vi\%, cooking, drying, and other community services for improving the quality of life. ${ }^{[3]}$

To address global climate change concerns arising from greenhouse gas emissions, Jawaharlal Nehru National Solar Mission (JNNSM) has been launched under the aegis of the National Action Plan on Climate Change in 2008. The mission aims to achieve landmark solar electricity capacity addition of 20,000 MW in 2022, and driving down the cost towards grid parity with coal-based thermal power in 2030. Obviously, the mission has more focus to grid connected solar power. A number of financial measures and fiscal policies have been announced. Under its phase I (2010-2013) as against the target of 1000-2000 MW grid connected (both SPV and solar 
thermal) and $200 \mathrm{MW}$ off-grid solar electricity, besides low temperature applications, the achievements as on March 2013 are 979 MW capacity of grid connected solar power and $118 \mathrm{MW}$ off-grid projects in various stages of implementation.

Phase II of the mission is just starting. When the said mission goals are met, up to 7 per cent contribution in India's total power installed capacity would come from solar energy. It would reduce the burden on coal imports by 3 percent (about 7 million tonnes/year) by 2017 and 5 percent by 2022. It would also lead to saving of 95 million tonnes of $\mathrm{CO}_{2}$ equivalent per annum, which means 2.6 percent reduction in the overall emissions.

Solar energy no doubt has a vast scope for India. Solar Photovoltaic (SPV) R\&D has been receiving considerable attention of the government since the beginning. Search for new materials as well as different fabrication techniques to achieve higher efficiency and cost-effectiveness has been targeted. Early research and developments from 1985-1992 were directed towards single-junction amorphous silicon solar cell technology. The emphasis then changed to large-area multi-junction amorphous silicon solar cell development comprising of thin-film solar cells based on cadmium telluride, copper indium diselenide, and silicon thin films. ${ }^{[4]}$ Hydrogenated amorphous (a-SiH), mono crystalline (mc-Si), and polycrystalline (pc-Si) silicon cells, as well as a host of other materials as III-V group compounds have been studied in the research mode for the development of solar cells. A few laboratories and academic institutions have been engaged in research on solar cell materials.

At the same time, the efforts have also been made towards development of indigenous Solar Photovoltaic (PV) production capabilities. In addition to this, government subsidies to support the deployment of SPV devices ${ }^{[5]}$ like solar lanterns, home systems, pumps, and small power plants etc., have been encouraged. A standard commercial design, which could supply energy up to $30 \mathrm{kWh} /$ day for use in industry or in remote location, was developed. The first grid connected $5 \mathrm{~kW}$ solar plant was operated at the Administrative Staff College of India, Hyderabad. The largest SPV plant capacity was of $100 \mathrm{~kW}$ capacity installed in Kalyanpur in Uttar Pradesh in 1992. The annual production of solar cells and photo voltaic modules in the country has since increased exponentially from $1 \mathrm{MW}$ in 1990 to $10 \mathrm{MW}$ in 1998, $240 \mathrm{MW}$ in 2008, and $700 \mathrm{MW}$ in 2012.
Several authors from India and abroad namely; Anantha et al. ${ }^{[6]}$ Kajikawa et al. ${ }^{[7]}$ and others have stressed on the importance of solar R\&D as a rapidly growing domain in energy research. Dye-sensitized and organic solar cells have started emerging as important research materials. In the recent years, R\&D thrust has shifted on improvement of the materials technology of crystalline silicon cells, development of thin-film technology, nanotechnology as well as module efficiency, development of new systems for cost reduction and improvements in balance of systems designs. To assess the current status of $\mathrm{R} \& \mathrm{D}$, this paper analyses research output in solar energy in India. World research output is also studied to know where the country stands in the global scene. This assessment for the period 2000-2009 (just before the start of solar mission) provides a baseline for future growth and establishes the need for increased $\mathrm{R} \& \mathrm{D}$ in meeting the set targets.

\section{Indicators for Research and Development}

The Research and Development (R\&D) is a systematic process to increase the stock of the knowledge of man, culture, and society at a place, which helps to devise innovation. To investigate the role of R\&D in solar energy, an attempt is made here to carry out the measurement of $R \& D$ in India vis-à-vis global scene. The OCED Manual ${ }^{\left[{ }^{[8]}\right.}$ not only characterizes R\&D, but is the most authoritative source for providing standards of $\mathrm{R} \& \mathrm{D}$ definition and $\mathrm{R} \& \mathrm{D}$ indicators which can be applied uniformly across the countries by policy makers. The indicators for R\&D INPUT are suggested as (i) $R \& D$ personal, (ii) $R \& D$ expenditure, and (iii) $\mathrm{R} \& \mathrm{D}$ infrastructure. Among these, data on $R \& D$ personal requires collection of information in a given timeframe, which can be classified into specific categories such as researchers, academicians, industry $\mathrm{R} \& \mathrm{D}$ personal and skilled workers. The R\&D expenditure provides information on significant resources available as well as flow of funds. The sources of data for these are both funding agencies and those engaged in research. The $R \& D$ infrastructure requires quantifying all information in terms of standard equipment available, laboratory facilities, specialized equipment, and other ancillaries such as journals and information sources.

It has been pointed out that because of data complexity for above parameters, dynamics of $R \& D$ input is not fully understood even for developed countries. Lack of data on these input parameters in the developing countries remains a further deterrent for them to asses R\&D. On the contrary, R\&D OUTPUT is measurable in terms of 
various bibliometric parameters. Bibliographic way to measure research output is in terms of publications and patents. Among these research publications, analysis can be considered a record of the research output in a systematic manner ${ }^{[9]}$ and is said to be the reflection of research activities and their results at a place. Both R\&D Input and Output have strong ties.

In terms of R\&D output, Georgeta et al., ${ }^{[10]}$ using bibliometric analysis for solar energy have illustrated that there is a correlation between federal R\&D funding and number of publications. Wilson et al. ${ }^{[11]}$ has shown that patents can also be considered a result of $R \& D$ spending and a measure of technological process. From a study of $\mathrm{R} \& \mathrm{D}$ funding and patent per capita across USA, a linear regression and close relationships was demonstrated. Patents help in tracking globalization pattern and can be considered as intermediate step between R\&D (upstream) and innovation. It has been noticed that $\mathrm{R} \& \mathrm{D}$ spending and output indicators can also be related for the purpose of measuring the economic efficiency of $\mathrm{R} \& \mathrm{D} /$ patent linkages. It has been pointed out that financial support and incentives, facilitation of technology transfer, and a large-scale research and development program are essential for technology development at a place. ${ }^{[12-14]}$

The purpose of this paper is not to discuss the technology complexities and adequacy of the Frascati Manual. However, the $R \& D$ process requires to be clarified at a more disaggregate level. Instead of basic applied taxonomy scheme, ${ }^{[15]}$ the process can be broken down into several steps to evaluate the exact nature of the $\mathrm{R} \& \mathrm{D}$ activity.

\section{METHODOLOGY ADOPTED}

The study involves scientific output in terms of research publications in solar energy with database indexed by 'Web of Science,' which is collection of online journals and academic citation index provided by Thomson Reuters. The data was downloaded from 2000-2009, and the keyword used for the search was "Solar" for measuring the research output on solar energy. 'Solar' included research specific publications related to solar cells, polycrystalline solar cells, concentrating PV, thin film, parabolic trough, solar power tower, and parabolic dish. The total number of publications as output during this period for key word "Solar" showed 27,024 records. A large number pertained to low temperature solar applications.

For examining the research output relating to materials and technologies at the world level and country level, the database included categories of "Materials science multidisciplinary" or "Energy fuels" or "Chemistry physical" or "Materials science ceramics" or "Chemistry multidisciplinary" or "Environmental sciences" or "Physics multidisciplinary" or "Materials science coatings films" or "Nanoscience nanotechnology" or "Multidisciplinary sciences" or "Engineering multidisciplinary" or "Electrochemistry" or "Chemistry applied" or "Chemistry organic" or "Polymer science" or "Engineering environmental." The publication of excluded categories was also checked one by one to avoid exclusion of any relevant paper from the search. The search was again refined as per document types. The document types included in this study was articles, proceeding papers, reviews, editorial material, meeting abstract, and book chapters.

The datasets on patents in the solar energy were obtained by using search engine (http://patinfo.nic.in/) supported by National information center (NIC), Department of information technology, Government of India. The patent search was made in single field search. The field used was "Search on title" with keyword "solar." For Indian patents, search was made in "Indian patent Search" using single field search for "Title" with keyword "solar" for the time period from 2000-2009.

\section{RESULTS AND DISCUSSIONS}

For bibliographic analysis in terms of indicators of research in solar energy Frascati manual indicator pattern has been adopted. Five types of output in terms of total number of R\&D publications and patents; publications per capita; technology-wise research output; R\&D infrastructure and growth trend in publications, is analyzed. Country-wise growth profile in research publications for five most productive countries is provided.

\section{Total R\&D Publications and Patents}

Worldwide active research on solar energy and solar power plants effectively began in 1975 resulting from the energy crises of 1970s. The R\&D publications in solar cells grew rapidly. From a study of world literature available in solar energy on research output ${ }^{[16]}$ in terms of publications, it was noted that USA has been the major producer of Solar Photovoltaic (SPV) R\&D output during the period 1970-1984 followed by India. In all 25 percent out of total publications i.e., 8194 appeared only on SPV.

Figure 1 represents the status of world publications under study during the period 2000-2009. The USA continues to 
hold the top position with 5327 publications. India shifted to $5^{\text {th }}$ position with total number as 1664 and had a share of 6.1 percent in the total. China, Germany, and Japan moved ahead of India. ${ }^{[17]}$ Guo et al. ${ }^{[18]}$ have illustrated that USA is the leading country in the area of nano-enhanced thin film solar cell R\&D. It was, however, pointed out that despite being top most player of R\&D, solar installed capacity in USA remained lower than Germany, Japan, and China.

In terms of numbers, these 25 countries can be grouped in four groups; USA, China, Germany, Japan, and India are leading and having more than 1500 publications. France, UK, Spain, South Korea, and Italy fell into the bracket having 1500-1000 research publications in ten years. Switzerland, Australia, Netherlands, Canada, Taiwan, Sweden, and Turkey contribution was in the third group of publications less than 1000 and more than 500. The countries namely Greece, Mexico, Russia, Brazil, Israel, Belgium, Poland, and Austria are having less than 500 papers in ten years [Table 1].

In percentage of total publications, it is seen that five leading countries USA (19.71\%), China (11.59\%), Germany (10.56\%), Japan (9.8\%), and India (6.15\%) together contribute $58 \%$ in the total publications. India has shown increasing trend in the research output (publications) in the emerging areas of solar PV research. However, Kostoff et al. ${ }^{[19]}$ stated that institutions associated with the least cited papers in solar energy research are mostly Indian, and this has not changed with time. A small percentage of research publications from India are in collaboration with other countries, largely USA, Germany, Japan, and South Korea.

Figures 2 and 3 represent the year-wise growth in number of publications and number of patents granted worldwide and for India.

The number of publications has increased steadily in the case of whole world, and number of patents have also increased, but with a slowdown occurring in 2004. On the other hand, for India, publications are on rise from 2001 onwards, but patenting effectively began after 2005, and only 19 patents were registered until 2009. India has 0.1 percent share in the global patents of solar energy unlike $\mathrm{R} \& \mathrm{D}$ publications, which is 6.1 percent.

\section{Publications Per Capita}

Total numbers of publications does not strictly showcase the research efforts of a country, but it does determine the relative research output. The $\mathrm{R} \& \mathrm{D}$ productivity i.e., number of publications on per capita basis shows the level of $R \& D$ output. Figure 4 shows indicative

\section{Table 1: Research productivity of 25 countries during} 2000-2009 in solar energy

\begin{tabular}{ll}
\hline No. of publications & Countries \\
\hline $1501 \geq 5500$ & USA, China, Germany, Japan, India \\
$1001 \geq 1500$ & France, England, Spain, South Korea, Italy \\
$501 \geq 1000$ & Switzerland, Australia, Netherlands, \\
& $\begin{array}{l}\text { Canada, Taiwan, Sweden, Turkey } \\
\leq 500\end{array}$ \\
& Greece, Mexico, Russia, Brazil, Israel, \\
& Belgium, Poland, Austria \\
\hline
\end{tabular}

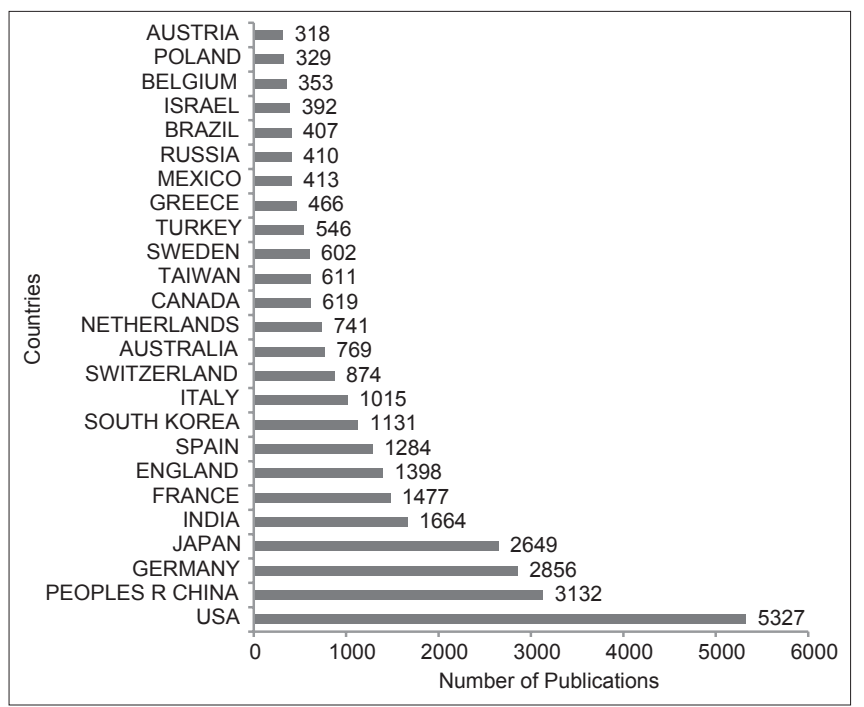

Figure 1: Solar energy research publications in leading countries indexed by Web of Science (2000-2009)

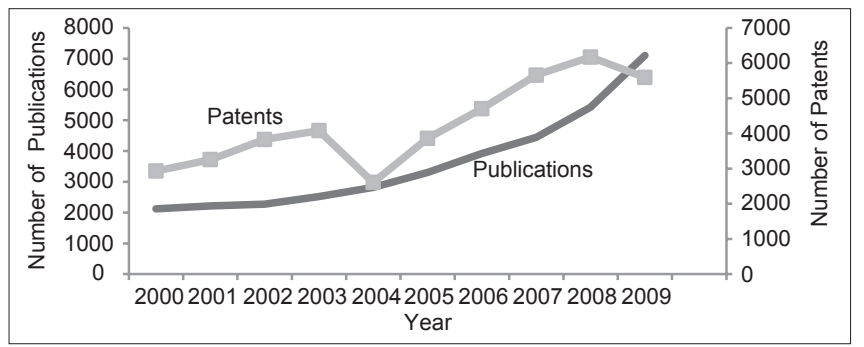

Figure 2: Year-wise growth in world publications and patents (2000-2009)

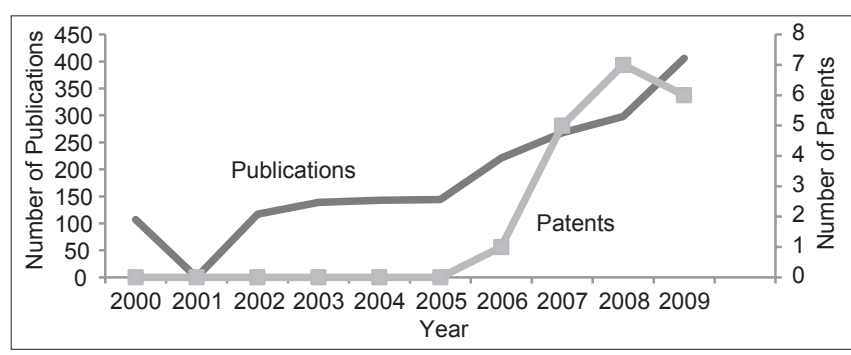

Figure 3: Year-wise growth of publications and patents in India (2000-2009) 
trends in the number of publications per 10 million populations for the period under study (2000-2009) in India and world.

Solar energy research output in terms of publications in India on per capita basis continues to be approximately one fourth that of the world (Figure 4).

\section{Technology-wise Research Output}

We further analyze the publications from India vs. world in terms of solar energy technologies. Both solar photovoltaic and solar thermal technologies namely; "Monocrystalline solar cells," "Polycrystalline solar

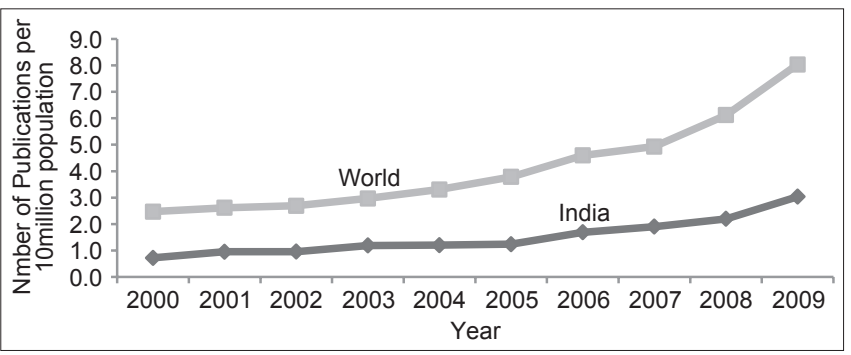

Figure 4: Year-wise growth in publications in solar energy on per capita basis cells," "Amorphous solar cells," "Thin films cells," "Concentrating PV,", "Parabolic trough," "Solar power tower," and "Parabolic dish" are selected as keywords for the search [Table 2].

It was found that yearly output of publications for thin films and amorphous cells is maximum during 2000-2009 worldwide, whereas solar thermal technologies such as; parabolic trough, central power tower, concentrating PV, and parabolic dish have began but grew with much smaller output globally. India performed well in polycrystalline, amorphous, and thin films solar cell research but lagged behind in monocrystalline photovoltaic and solar thermal technologies during the period under study.

There is hardly any research publication seen in concentrated solar PV, solar central tower, and parabolic dish from India before 2010. This may change after the launch of the national solar mission. The role of mission in encouraging greater investment and $R \& D$ than otherwise would have occurred can be inferred from a quantum jump seen in grid connected solar electricity from 8 MW in January 2010 to 979 MW in March 2013.

Table 2: Number of publications on various solar energy technologies in World and India 2000-2009

\begin{tabular}{|c|c|c|c|c|c|c|c|c|c|c|}
\hline Solar technology year & 2000 & 2001 & 2002 & 2003 & 2004 & 2005 & 2006 & 2007 & 2008 & 2009 \\
\hline \multicolumn{11}{|l|}{ Monocrystalline cells } \\
\hline World & 13 & 17 & 18 & 22 & 19 & 14 & 32 & 25 & 23 & 14 \\
\hline India & 0 & 0 & 0 & 1 & 0 & 3 & 1 & 1 & 2 & 2 \\
\hline \multicolumn{11}{|l|}{ Polycrystalline cells } \\
\hline World & 92 & 122 & 90 & 112 & 98 & 148 & 178 & 153 & 164 & 220 \\
\hline India & 0 & 11 & 13 & 10 & 10 & 12 & 22 & 24 & 29 & 26 \\
\hline \multicolumn{11}{|l|}{ Amorphous cells } \\
\hline World & 98 & 125 & 158 & 156 & 182 & 176 & 297 & 210 & 305 & 370 \\
\hline India & 5 & 3 & 16 & 13 & 7 & 4 & 30 & 10 & 24 & 23 \\
\hline \multicolumn{11}{|l|}{ Thin films cells } \\
\hline World & 344 & 397 & 402 & 516 & 568 & 696 & 902 & 923 & 1178 & 1675 \\
\hline India & 26 & 22 & 34 & 40 & 43 & 51 & 88 & 88 & 101 & 130 \\
\hline \multicolumn{11}{|l|}{ Parabolic trough } \\
\hline World & 0 & 11 & 13 & 0 & 20 & 11 & 18 & 29 & 32 & 28 \\
\hline India & 0 & 1 & 1 & 0 & 0 & 0 & 1 & 4 & 4 & 1 \\
\hline \multicolumn{11}{|l|}{ Concentrated PV } \\
\hline World & 3 & 3 & 0 & 2 & 4 & 5 & 6 & 12 & 12 & 13 \\
\hline India & 0 & 0 & 0 & 0 & 0 & 0 & 0 & 0 & 1 & 0 \\
\hline \multicolumn{11}{|l|}{ Solar power tower } \\
\hline World & 3 & 6 & 10 & 7 & 9 & 3 & 12 & 10 & 18 & 13 \\
\hline India & 0 & 1 & 0 & 0 & 0 & 0 & 0 & 0 & 1 & 0 \\
\hline \multicolumn{11}{|l|}{ Parabolic dish } \\
\hline World & 0 & 2 & 3 & 3 & 3 & 0 & 1 & 5 & 7 & 6 \\
\hline India & 2 & 0 & 0 & 0 & 0 & 0 & 0 & 2 & 1 & 2 \\
\hline
\end{tabular}




\section{R\&D Infrastructure}

The analysis of R\&D infrastructure is made based on the secondary data. In India, most research is government sponsored by the agencies namely Ministry of New and Renewable Energy (MNRE), Council of Scientific and Industrial Research (CSIR), Department of Science and Technology (DST) and University Grant Commission (UGC) who are the main players. It is seen that basic research is mainly conducted by Universities and Academic Institutions, while applied research is mainly conducted in various R\&D Centers and Laboratories. Corporate sector data are not accessible. It is concluded that private sector contribution in solar $\mathrm{R} \& \mathrm{D}$ has been minimal as in other fields.

From the citation point of view, it was seen that academic institutions significantly contributing to the growth of infrastructure in solar energy $R \& D$ are; Indian Institutes of Technology, Shivaji University, Indian Association of Cultivation of Science, Jai Narain Vyas University, Indian Institute of Science, Anna University, Central Electrochemical Research Institute, and National Institutes of Technology. These were top most productive institutions working on R\&D of solar energy in India and contributing to $R \& D$ publications. The institutes listed below in Table 3 accounts for approximately 63 percent of total publications.

\begin{tabular}{lc} 
Table 3: List of top Institutes/Universities/Laboratories \\
in India and their research output (2000-2009) \\
\hline Institutions & $\begin{array}{c}\text { Number of } \\
\text { publications }\end{array}$ \\
\hline Indian Institutes of Technology & 268 \\
Shivaji University, Mumbai & 71 \\
Indian Association for Cultivation of Science, Kolkata & 70 \\
Jai Narain Vyas University, Jodhpur & 62 \\
Indian Institute of Science, Bangalore & 59 \\
Anna University, Chennai & 57 \\
Central Electrochemical Research Institute, Chennai & 53 \\
Alagappa University, Tamil Nadu & 44 \\
National Physical Laboratory, Delhi & 43 \\
University of Delhi, Delhi & 37 \\
Jadavpur University, Kolkata & 35 \\
Sri Venkateswara University, Andhra Pradesh & 32 \\
National Institute of Technology & 31 \\
Defence Laboratory & 29 \\
Banaras Hindu University, Varanasi & 28 \\
Annamalai University, Tamil Nadu & 23 \\
Physical Research Laboratory, Ahmadabad & 22 \\
Cochin University of Science and Technology, Kerala & 21 \\
Bhabha Atomic Research Center, Mumbai & 19 \\
Indian Institute of Chemical Technology, Chennai & 19 \\
\hline
\end{tabular}

The remaining 37 percent is carried out in more than 50 other academic centers and industry.

Undeniably, the MNRE has been the largest contributor to solar R\&D infrastructure and has increased its share significantly during the $11^{\text {th }}$ and $12^{\text {th }}$ Five Year Plans. The power utility National Thermal Power Corporation (NTPC) has come forward to support expansion of the solar capacity during phase I of the national mission. A new thrust to collaborative solar energy research is also being provided under PACE-R of Indo-US Clean Energy Center, besides other bilateral and multinational programs.

\section{Trends in Growth of Publications-India vs. World}

The research publications of the five most productive countries in the first half and second half of the duration under study i.e., 5 years each from 2000-2004 and 2005-2009, is depicted in Figure 5. In Germany, the number of publications increased by 32 percent, whereas China recorded highest increase as 80 percent. It is seen that China and India had almost similar research output during 2000-2004 as 529 and 524, respectively. But China has jumped to second position from the fourth by having an output of 2603 during 2005-2009, which is five times more as compared to 2000-2004, while India could only double the number to 1140. The Germany and Japan who are ahead in implementation of solar energy showed a slowdown in research output in the second half.

\section{CONCLUSIONS}

This paper presents a study based on Web of Science publication database in the domain of solar energy R\&D in India. Using publication and patent data, analysis from 2000-2009 has been carried out. An attempt has been made to develop preliminary $\mathrm{R} \& \mathrm{D}$ output indicators, and data are analyzed in terms of number of publications, technology-wise distribution, and growth of infrastructure. India is among the five leading countries in term of number of publications. Results show that research output in solar

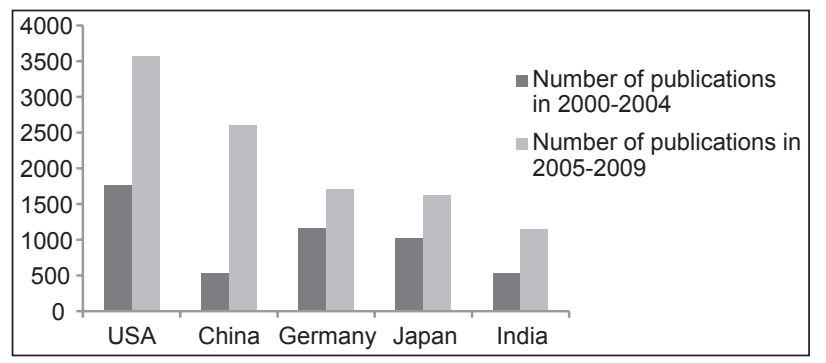

Figure 5: R\&D publications in top five countries 
energy in India almost doubled in 2005-2009 as compared to 2000-2004. China, however, stands out in growth in solar $\mathrm{R} \& \mathrm{D}$ by increasing their research output during the same period by five times.

In terms of research output, thin film technology is performing highest both in the world and in India. It is also seen that in India, the publication number has certainly increased, but the per capita publication is much on a lower side. Solar thermal research is yet to pick up. The patents are almost negligible during the period under study. No doubt, a robust R\&D infrastructure exists in the country for taking up the challenge of solar energy development. However, research contribution is not keeping pace with the world trends. Only a few institutions are engaged in research. A compelling observation is that despite adequate human resources and infrastructure, Indian solar R\&D is lagging behind. International collaborations are few.

There is a strong correlation between R\&D Input and technological growth. Phase II of the mission is just started. Sustenance of financial incentives alone is becoming doubtful. The potential role of the mission in encouraging a greater investment and highest level of $R \& D$ than that would otherwise have occurred is to be seen in the light of discussions presented here. The research frontiers are moving fast. Time horizon and techniques employed are important. It is recommended that a phenomenal increase in the investment for goal-oriented and internationally collaborative solar R\&D both from government and industry is made to achieve the extraordinary goal of the Jawaharlal Nehru National Solar Mission by 2022 and to take efforts further to international level.

\section{ACKNOWLEDGEMENTS}

First author conveys her sincere thanks to Prof. Samir Brahmachari, Director General, Council for Scientific and Industrial Research and the HRDG unit of CSIR for the award of Emeritus Scientist project on Clean Energy R\&D in India: Opportunities and Challenges. We are thankful to Prof. S. K. Sopory, Vice Chancellor, Jawaharlal Nehru University for the encouragement.

\section{REFERENCES}

1. International Energy Agency, Energy Technology Perspectives (2010). Available from: http://www.iea.org/techno/ etp/index.asp [Last accessed on $25^{\text {th }}$ November 2012].

2. Goel M. Energy from sun, in Energy Sources and Global Warming. New Delhi: Allied Publishers Ltd; 2005.

3. Chandrasekar B. Promotion of SPV programme in India. vol 1. IREDA News; 2004 no. 343.

4. Bhargava B. Overview of photovoltaic technologies in India. Solar energy mater solar cells 2001:639-46. Available from: http:// ac.elscdn.com [Last accessed on 30th March 2012].

5. Sastry EV. "The photovoltaic program in India", Photovoltaic Specialists Conference, 2002. Conference Record of the 29th IEEE; 2002.

6. Anantha A. (1997) Solar photovoltaic as an energy source for India, energy conversion engineering conference. IECEC-97. Proceedings of the $32^{\text {nd }}$ Intersociety. Available from: http://ieeexplore. ieee.org/stamp/stamp.jsp?tp=and arnumber=658231 [Last accessed on $26^{\text {th }}$ May 2012].

7. Kajikawa Y, Fujimoto S, Takeda Y, Sakata I, Matsushima K. (2006). Detection of emerging research fronts in solar cell research. $12^{\text {th }}$ International Conference on Scientometrics and Informetrics (ISSI2009), in Rio de Janeiro, Brazil; July 14-17 2009.

8. Frascati manual: Main definitions and conventions for the measurement of research and experimental development (R\&D), OCED/GD (94)84.

9. Gangan P. How much should a nation spend on academic research? Curr Sci., 2010;98:1182-4.

10. Georgeta V, Woon WL, Madnick S. Measuring innovation using bibliometric techniques: The case of solar photovoltaic industry, Advancing the study of innovation and globalization in organizations (ASIGO) Conference in Nurnberg, German; 2009.

11. Wilson D. Are we running out of new ideas? A look at patents and R\&D”, FRBSF Economic letter, Number; 2003.

12. Jacobsson $S$, Johnson $A$. The diffusion of renewable energy technology: An analytical framework and key issues for research. Energy Policy 2000;28:625-40.

13. Stephens JC, Wilson EJ, Peterson TR. Socio-political evaluation of energy deployment (SPEED): An integrated research framework analyzing energy technology deployment. Technol Forecast Soc Change 2008;75:1224-46.

14. Edkins $M$, Winkler $H$, Marquard A. Large-scale rollout of concentrating solar power in South Africa. Energy Research Centre, University of Cape Town, South Africa; 2009.

15. Amsden AH, Tschang FT. A new approach to assessing the technological complexity of different categories of R\&D. Res Policy 2003;32:553-72.

16. Garg KC, Sharma P. Solar power research: A scientometric study of world literature. Scientometrics 1991;21:147-57.

17. Ichiro S, Hajime S, Toshihiro I. Structure of international research collaboration in wind and solar energy, Proceedings in the 2011, IEEE, IEEM; 2011.

18. Guo Y, Huang L, Porter AL. The research profiling method applied to nano-enhanced, thin-film solar cells. R and D Management, 2010;40:195-208.

19. Kostoff RN, Johnson D, Bowles CA, Bhattacharya S, Icenhour AS, Nikodym K, et al. Assessment of India's Research Literature. Technol Forecast Soc Change 2009:1574-608.

How to cite this article: Goel M, Maurya V, Desai PN. R \& D indicators and mapping of solar energy research output in India. J Sci Res 2013;2:52-8.

Source of Support: Nil, Conflict of Interest: None declared 